\title{
O trabalho perante a lei: os mineiros de carvão na Justiça do Trabalho em São Jerônimo, RS (1946-1954)
}

\author{
Clarice Gontarski Speranza*
}

\section{RESUMO}

O artigo apresenta uma análise de 5.708 processos trabalhistas envolvendo mineiros de carvão do Rio Grande do Sul entre 1946 e 1954, nos primeiros anos após a implantação de uma Junta de Conciliação e Julgamento no município de São Jerônimo, polo produtor do minério na época. São analisados a iniciativa das açôes, seus resultados, bem como as principais demandas dos operários no Judiciário trabalhista. O estudo revela uma superioridade numérica das reclamatórias propostas pelas empresas mineradoras contra os trabalhadores, bem como dos resultados favoráveis a elas, enquanto os acordos são os resultados mais significativos dos processos movidos pelos operários. Quase a metade das açôes de iniciativa dos trabalhadores reivindica o pagamento do descanso semanal remunerado, o que indica que a lei que criava esse direito, de 1949, náo era cumprida.

Palavras-chave: trabalhadores; Justiça; mineiros; lei; trabalho.

\section{ABSTRACT}

The article analyzes 5,708 labor lawsuits involving coal miners of Rio Grande do Sul, Brazil, between 1946 and 1954, the first years after the establishment of the Labour Justice in the region of São Jerônimo, a major coal producer at this time. It focuses the initiative of the actions, its results, and the main demands of the workers in the court. The study reveals a numerical superiority of lawsuits proposed by mining companies against workers, and the results favorable to the enterprises, although the agreements are the most significant results of the lawsuits filed by workers. Almost half of the actions brought by the workers demanded the payment of the paid weekly rest, indicating that the 1949 law that regulate that right was not fulfilled.

Keywords: workers; Justice; coal miners; law; labour. 
As distantes vilas de Arroio dos Ratos e de Butiá, em São Jerônimo, no Rio Grande do Sul, abrigavam, por volta de 1943, uma das maiores concentraçóes de trabalhadores do país. Viviam na região cerca de 7 mil mineiros, ${ }^{1}$ dedicados a extrair o carvão mineral das entranhas da terra. O Rio Grande do Sul era então o maior produtor nacional do minério, e a exploração do carvão havia sido especialmente beneficiada pela política varguista (desde o Governo Provisório) por meio de decretos que estabeleciam cotas obrigatórias mínimas para o consumo do produto nacional em relação ao importado. ${ }^{2}$

A exploração do minério obedecia aos padróes tradicionais de extração de carvão: os mineiros estavam concentrados em vilas-fábricas, onde contavam com um significativo aparato de bem-estar social. ${ }^{3}$ Os habitantes de Arroio dos Ratos e Butiá — os dois polos principais de exploraçáo - viviam em moradias e terrenos de propriedade do Consórcio Administrador de Empresas de Mineração (Cadem) - união das duas principais mineradoras (Companhia Estrada de Ferro e Minas São Jerônimo e Companhia Carbonífera Riograndense, mais tarde Companhia Carbonífera Minas do Butiá). Nos anos 1940, dispunham de hospital, maternidade, posto de puericultura, armazém, grupo escolar, espaços de lazer, times de futebol, distribuição de energia elétrica, clubes de lazer e até cinemas. ${ }^{4}$

\footnotetext{
${ }^{1}$ Inspeção do Ministério do Trabalho nas minas de Arroio dos Ratos e Butiá encontrou 6.929 operários em dezembro de 1943. Documento anexo à reclamatória trabalhista 14/46 (fl. 96). Processos Trabalhistas de São Jerônimo/RS (1938-1947). Coleção Acervos. Memorial da Justiça do Trabalho no Rio Grande do Sul (MJTRS). CD-ROM. Esse artigo é uma versão modificada de um capítulo da tese de doutorado da autora (Cavando direitos: as leis trabalhistas e os conflitos entre trabalhadores e patröes nas minas do Rio Grande do Sul nos anos 40 e 50), defendida no Programa de Pós-Graduação em História da Universidade Federal do Rio Grande do Sul (UFRGS) em 2012, com orientação do professor Benito Bisso Schmidt e auxílio de bolsa Capes.

${ }^{2}$ Em 1931, o Decreto Federal no 20.889, do Governo Provisório, alavanca o setor ao definir um percentual mínimo de $10 \%$ para o consumo do carváo nacional em relação ao estrangeiro. Em 1936, o Decreto Federal no 1.828 aumenta o percentual mínimo de consumo de carvão brasileiro no país para 20\%. Entre 1932 e 1939, 82\% da produção nacional do minério vinha do Rio Grande do Sul (MINISTÉRIO DAS RELAÇÓES EXTERIORES. Brazil 1940/41: an economic, social and geographic survey. Rio de Janeiro: Ministério das Relaçóes Exteriores, 1942). ${ }^{3}$ Sobre as características industriais e as relaçôes sociais na exploração de carvão na Europa, ver TREMPÉ, Rolande. Les caractéristiques du syndicalisme minier français et son apport au mouvement ouvrier français. Halifax, v. 16, n. 1, p. 144-154, 1981; e DENNIS, Norman; HENRIQUES, Fernando; SLAUGHTER, Clifford. Coal is our life. Londres: Tavistock Publications, 1956.

${ }^{4}$ A vida nessas vilas mineiras motivou historiadores locais como SIMCH, Carlos Alfredo. Monografia de São Jerônimo. Porto Alegre: Imprensa Oficial, 1961; e HOFF, Gertrudes Novak. Butiá em busca de sua história. Arroio dos Ratos: PBS, 1992. Na literatura acadêmica, a exploração de carvão no Rio Grande do Sul é o tema de trabalhos como os de ECKERT, Cornelia. Os homens da mina: um estudo das condiçóes de vida e representaçóes dos mineiros de carvão em Charqueadas/RS. Dissertaçáao (mestrado em antropologia) — Programa de Pós-Graduação em Antropologia, Sociologia e Ciência Política, Universidade Federal do Rio Grande do Sul, Porto Alegre, 1985; CIOCCARI, Marta. Ecos do subterrâneo: estudo antropológico do cotidiano e memória da comunidade de mineiros de carvão de Minas do Leão (RS). Dissertação (mestrado em antropologia social) - Programa de Pós-Graduação em Antropologia Social, Universidade Federal do Rio Grande do Sul, Porto Alegre, 2004; e CIOCCARI, Marta. Do gosto da mina, do jogo e da revolta: um estudo antropológico sobre a construção da honra numa comunidade de mineiros de carvão. Tese (doutorado em antropologia) - Programa de Pós-Graduação em Antropologia Social, Museu Nacional, Rio de Janeiro, 2010; e SILVA, Cristina Ennes da. Nas profundezas da terra: um estudo sobre a região carbonífera do Rio Grande do Sul.
} 
Essa estrutura convivia, paradoxalmente, com níveis intensos de exploração de mão de obra. Os mineiros não dispunham de condiçôes mínimas de trabalho: sem água potável no subsolo, sem refeitório, banheiro ou qualquer equipamento de segurança, estavam sujeitos a longas jornadas e a acidentes fatais ou incapacitantes. Demissôes em massa, protestos, revolta pelas péssimas condiçôes de trabalho e, finalmente, milhares de açôes na Justiça foram tão determinantes para a experiência da classe quanto a dominação em moldes paternalistas promovida pela direção do Cadem. ${ }^{5}$

O carvão gaúcho tinha grande importância para a economia, alimentando a Viação Férrea do Rio Grande do Sul e abastecendo de energia elétrica a capital do estado, Porto Alegre, então com cerca de 260 mil habitantes. Durante a Segunda Guerra Mundial, o minério gaúcho chegou a ser exportado para outros estados brasileiros e para a Argentina e o Uruguai. O fim do conflito e o início do governo Dutra trouxeram uma paulatina decadência ao setor minerador do Rio Grande do Sul; as compras de carvão estrangeiro foram regularizadas no país e foi introduzido, aos poucos, um substituto mais barato do produto nacional: o óleo combustível (fuel oil). O crescimento da exploraçâo do carvão em Santa Catarina, a partir de 1946, e a entrada de uma autarquia estatal no setor, em 1947 (o Departamento Autônomo de Carvão Mineral — DACM), ajudaram a modificar o quadro de liderança nacional e monopólio privado estadual. Ao mesmo tempo que a produçáo de carvão decaía no Rio Grande do Sul, os mineiros participavam de greves com ampla participaçáo, como em 1946. Além disso, encabeçaram movimentos pelo cumprimento da legislação trabalhista, num momento de consolidação do aparato institucional de regulação do trabalho no Brasil.

O presente artigo apresenta a análise de um corpus de 5.708 processos trabalhistas, propostos por trabalhadores e por patróes da mineração de carvão na Junta de Conciliação e Julgamento (JCJ) da São Jerônimo, entre 1946 e 1954. A intenção principal é identificar o impacto que a instalação da Junta da Justiça do Trabalho em São Jerônimo - a quarta do Rio Grande do Sul e segunda do interior do estado - teve nas relaçôes de trabalho nas minas de carvão.

Foram examinados, inicialmente, 6.637 processos da JCJ entre 1946 e 1954, todos atualmente conservados no Memorial da Justiça do Trabalho no Rio Grande do Sul (MJTRS). Entre esses, foram definidas como universo para a pesquisa 5.708 açóes, ou seja, todas aquelas referentes a empresas ou empreiteiras da mineração de carvão, ${ }^{6} 826$ estando disponíveis

Tese (doutorado em história) — Programa de Pós-Graduação em História, Pontifícia Universidade Católica do Rio Grande do Sul, Porto Alegre, 2007.

${ }^{5}$ Sobre as ações judiciais dos mineiros de carvão durante a primeira metade dos anos 1940, ver SPERANZA, Clarice Gontarski. Os mineiros de carvão, seus patrôes e as leis sobre trabalho: conflitos e estratégias durante a Segunda Guerra Mundial. Revista Brasileira de História (on-line), v. 32, n. 64, p. 129-148, 2012.

${ }^{6}$ Os dados referentes ao último ano da amostra pesquisada (1954) devem ser vistos com cuidado. Como foram retirados dos livros de audiências realizadas pela Junta naquele ano, não aparecem lá as reclamatórias impetradas em 1954 e julgadas em 1955. Em compensação, entre os anos de 1946 e 1953, temos acesso a praticamente a totalidade das reclamatórias impetradas. 
em sua totalidade e o restante, parcialmente (somente as atas de audiências, reunidas em livros anuais dispostos cronologicamente).

$\mathrm{Na}$ historiografia brasileira atual, multiplicam-se os trabalhos que utilizam processos trabalhistas como fontes, bem como a produção que investiga as formas como a legislação brasileira afetou a (ou foi afetada pela) experiência dos trabalhadores. ${ }^{7}$ Tais trabalhos possibilitam refletir sobre o papel do arcabouço legal na constituição da identidade, da organização e das açôes dos trabalhadores brasileiros. Os novos estudos esmiúçam a constituição das normas trabalhistas e iluminam aspectos que haviam sido negligenciados nas interpretaçóes anteriores. Eles se unem a um movimento geral da historiografia do trabalho que acentua o papel da lei como campo de conflitos e tenta romper com a clivagem historiográfica estabelecida entre escravidão e trabalho assalariado. ${ }^{8}$

Este artigo se divide em três partes. Na primeira, esboço um quadro geral do universo pesquisado e apresento a movimentação dos processos da JCJ de 1946 a 1954. A seguir, analiso as açóes propostas pelas empresas de mineração, e, depois, aquelas de iniciativa dos trabalhadores. Assim, tentei entender as motivaçóes e dinâmicas dos mineiros de carvão e de seus patróes na relaçáo com o campo jurídico trabalhista em seus primeiros anos de implantação nas minas. A perspectiva que rege a pesquisa é que a interpretação das normas legais é um campo de luta social que extrapola a própria discussão da doutrina jurídica (porém expressando-se e reconstituindo-se nela), bem como reflete e, ao mesmo tempo, constitui as condiçôes materiais de existência. Dito de forma mais simples: a lei (em seus diversos âmbitos) expressa, mas também configura a experiência concreta do trabalhador.?

\footnotetext{
${ }^{7}$ Como exemplos: GOMES, Angela de Castro. Burguesia e trabalho: política e legislação social no Brasil 1917-1937. Rio de Janeiro: Campus, 1979; SOUZA, Samuel Fernando de. Coagidos ou subornados: trabalhadores, sindicatos, Estado e leis do trabalho nos anos 1930. Tese (doutorado em história) — Instituto de Filosofia e Ciências Humanas, Universidade de Campinas, Campinas, 2007; CORREA, Larissa Rosa. A tessitura dos direitos: patróes e empregados na Justiça do Trabalho, 1953-1964. São Paulo: LTr/Fapesp, 2011; SOUZA, Edinaldo Antonio Oliveira. Lei e costume: experiências de trabalhadores na Justiça do Trabalho (Recôncavo Sul, Bahia, 1940-1960). Dissertação (mestrado em história) — Programa de Pós-Graduação em História, Universidade Federal da Bahia, Salvador, 2008.

${ }^{8}$ A lista é extensa, mas vale citar CHALHOUB, Sidney. Visóes da liberdade: uma história das últimas décadas da escravidão na Corte. São Paulo: Companhia das Letras, 1990; MATTOS, Marcelo Badaró. Escravizados e livres: experiências comuns na formaçáo da classe trabalhadora carioca. Rio de Janeiro: Bom Texto, 2008; LARA, Silvia; MENDONÇA, Joseli (Org.). Direitos e justiças no Brasil. Campinas: Unicamp, 2006. Sobre esse movimento geral de aproximação, ver LARA, Silvia. Escravidão, cidadania e história do trabalho no Brasil. Projeto História, São Paulo, n. 16, p. 15-38, 1998.

${ }_{9}^{9}$ As linhas gerais dessa reflexão inspiram-se em THOMPSON, E. P. Senhores e caçadores: a origem da lei negra. Rio de Janeiro: Paz e Terra, 1987.
} 


\section{As vilas mineiras e a instalação da Justiça do Trabalho}

A JCJ de São Jerônimo foi instalada no último dia de julho de 1945. Sua criação foi determinada pelo Decreto no 7.552 , editado pelo governo federal em maio de 1945 , e certamente foi influenciada pela concentração operária na região. Além disso, o decreto saía no mês seguinte a uma série de greves de trabalhadores, sendo os mineiros uma das categorias que paralisaram. No ano seguinte, uma nova greve mobilizaria a regiáo e demonstraria a visibilidade política dos mineiros - o início da paralisação de 1946 (que durou 36 dias) coincidiu com a posse do presidente Dutra, em 31 de janeiro —, motivando a intervençấo militar nas minas e merecendo a atençáo do governo federal e da embaixada norte-americana (em relatório, o adido trabalhista Edward J. Rowell apressou-se em dizer que a paralisação refletia tanto as pressóes econômicas sobre os operários quanto a "inadequação, ou ao menos, a falta de confiança dos trabalhadores no sistema brasileiro de Justiça do Trabalho"). ${ }^{10}$

As JCJs eram constituídas por um presidente, bacharel em direito, e dois representantes classistas (vogais), um dos empregadores e outro dos empregados. Os processos partiam de uma reclamação provinda de uma das partes (os trabalhadores ou as empresas), a qual era posteriormente ouvida em juízo, nas audiências. Além do trabalhador e do preposto (representante) da empresa, também eram inquiridas testemunhas, se houvesse. Levar testemunhas era um direito tanto do reclamante (aquele que impetrava a ação) quanto do reclamado (aquele que respondia à ação). Após tudo isso, e das razóes (argumentação) finais de ambas as partes, o juiz-presidente se manifestava, e era acompanhado por pelo menos um dos juízes classistas em sua decisão (a imensa maioria das decisões na JCJ de São Jerônimo era por unanimidade). Caso uma das partes (patrão ou trabalhador) não ficasse satisfeita com a sentença, poderia recorrer ao Tribunal Regional do Trabalho da $4^{a}$ Região, com sede em Porto Alegre, ${ }^{11}$ e, posteriormente, ao Tribunal Superior do Trabalho, em Brasília.

O tipo de fontes de que dispomos entre 1948 e 1954 - as atas de audiência dos processos - náo permite conhecer ou mesmo definir o número de recursos enviados ao TRT entre 1948 e 1954. Nos anos anteriores, porém, a quantidade de recursos não era totalmente

\footnotetext{
${ }^{10}$ Rowell preparou um relatório de 26 páginas sobre o movimento. Sua interpretação foi construída basicamente a partir de relatos de jornais e leitura de decretos e discursos das autoridades brasileiras. Na opiniáo do adido, o conflito representava uma "falta de confiança no governo de parte dos trabalhadores e de suas lideranças". ROWELL, Edward J. Rio Grande do Sul coal strike. Rio de Janeiro: American Embassy, 21-31946. U.S. National Archives. Agradeço ao prof. dr. Alexandre Fortes (UFRRJ) o envio de uma cópia desse documento.

${ }^{11}$ Até setembro de 1946, 4ํㅡㄹ Conselho Regional do Trabalho (CRT). Os primeiros oito Conselhos Regionais do Trabalho no Brasil foram instalados em 1941. O CRT era composto por um juiz presidente e quatro vogais. Julgavam os recursos das sentenças de primeira instância e também os dissídios coletivos. Ver SUSSEKIND, Arnaldo. Manual da Justiça do Trabalho. Rio de Janeiro: Edição Revista do Trabalho, 1942; e NASCIMENTO, Amauri Mascaro; FERRARI, Irany; MARTINS FILHO, Ives Gandra da Silva. História do trabalho, do direito do trabalho e da Justiça do Trabalho. Sáo Paulo: LTr, 1998.
} 
desprezível, apesar de seu resultado ser pífio. Em 1946, há 22 recursos (12 pelas empresas e 10 pelos trabalhadores). Porém, em 1947, dos 668 processos, há apenas quatro recursos (três pelas empresas e um por trabalhador). O que talvez explique essa queda é o fato de que o reexame das sentenças na segunda instância provou ser bastante ineficaz para as partes em 1946: dos 22 recursos, 21 tiveram a decisão da Junta mantida.

Em 1946 e em 1947, há somente um caso de recurso à terceira instância (TST) para cada ano, ambos das empresas de mineração. Nos dois, foram mantidas as decisôes dos tribunais anteriores. No processo de 1946, referente à demissão de um líder grevista, uma das empresas ainda recorreu ao Supremo Tribunal Federal (STF), sem sucesso. Esses números iniciais já nos permitem afirmar a importância da primeira instância para a resolução dos conflitos trabalhistas no âmbito jurídico, pelo menos no caso de São Jerônimo, já que a maioria das decisóes da Junta era mantida nos tribunais superiores. Além disso, indicam o prestígio e a respeitabilidade profissional impostos desde cedo pelo juiz presidente da JCJ de São Jerônimo (entre 1946 e 1954), Carlos Alberto Barata Silva, o que foi ratificado por sua trajetória posterior na carreira jurídica. ${ }^{12}$

Em relação à distribuição anual das 5.708 reclamatórias referentes a empresas ou empreiteiros de mineração na Junta de São Jerônimo entre 1946 e 1954, podemos observar um crescimento paulatino das demandas. $\mathrm{O}$ avanço das reclamatórias relacionadas à mineração assume proporçôes geométricas nos três primeiros anos da amostra (1946-1948), alcançando a seguir alguma estabilidade (1949-1952). Posteriormente, a amostra apresenta uma tendência de queda (1953-1954). Os picos ocorreram em 1949 e 1952, e as maiores diminuiçóes, em 1953 e $1954 .{ }^{13}$ Quanto às açóes não relacionadas à mineração, há um crescimento um pouco mais acentuado em 1950 e em 1953. Essa distribuição pode ser mais bem visualizada no gráfico 1 .

\footnotetext{
${ }^{12}$ Nascido em Rio Grande (RS) em 1920, Barata Silva construiu longa carreira no Judiciário Trabalhista, tendo sido posteriormente juiz e presidente do Tribunal Regional do Trabalho da $4^{a}$ Regiáo (1965-1971), e ministro e presidente do TST (1982-1984). Barata Silva permaneceu até 1954 na Junta de São Jerônimo. TRIBUNAL SUPERIOR DO TRABALHO. A história da Justiça do Trabalho no Brasil: multiplicidade de olhares. Brasília: TST/Comissão de Documentação, 2011.

${ }^{13}$ Ressalvando a já mencionada parcialidade do levantamento neste último ano.
} 
Gráfico 1

Processos da JCJ de São Jerônimo referentes à mineração de carvão (1946-1954)

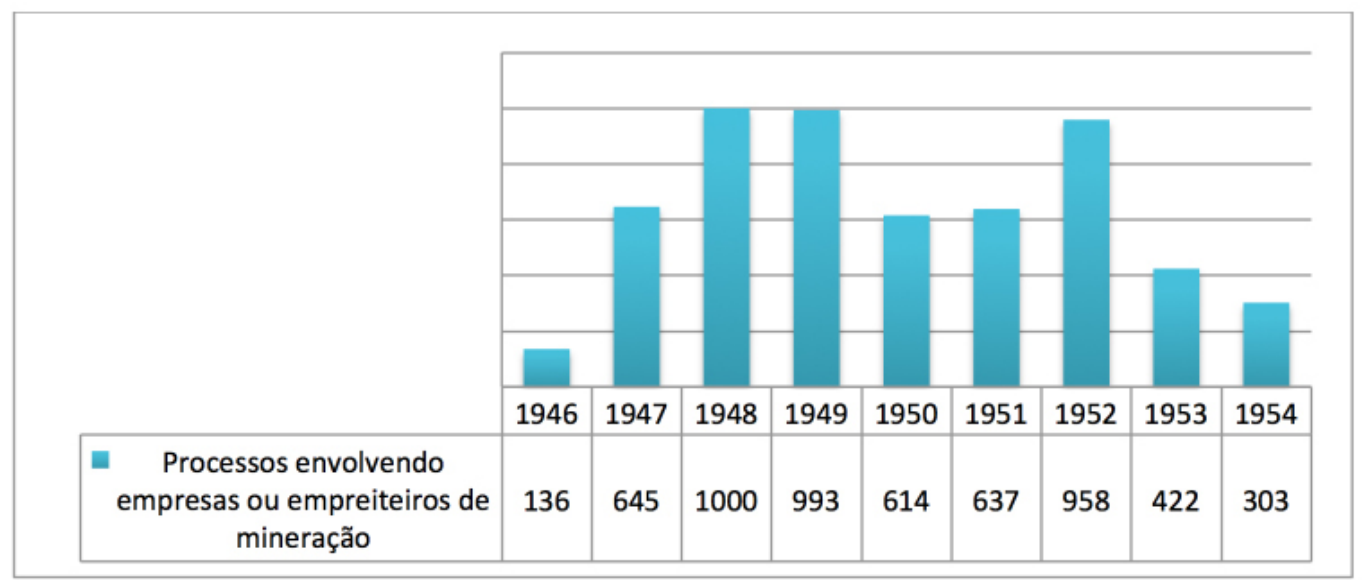

Fonte: Levantamento realizado a partir de processos e atas de audiências da JCJ de São Jerônimo/ MJTRS.

Ora, interessa já de início investigar os contornos desse crescimento dos processos trabalhistas relacionados à mineração. Tomando os dados referentes à iniciativa das 5.708 reclamatórias referentes a empresas ou empreiteiros de mineração entre 1946 e 1954, podemos tentar definir de quem parte a iniciativa das ações (patrôes ou empregados). Assim, chegamos aos seguintes resultados:

Gráfico 2

Iniciativa dos processos referentes à mineração na JCJ de São Jerônimo (1946-1954)

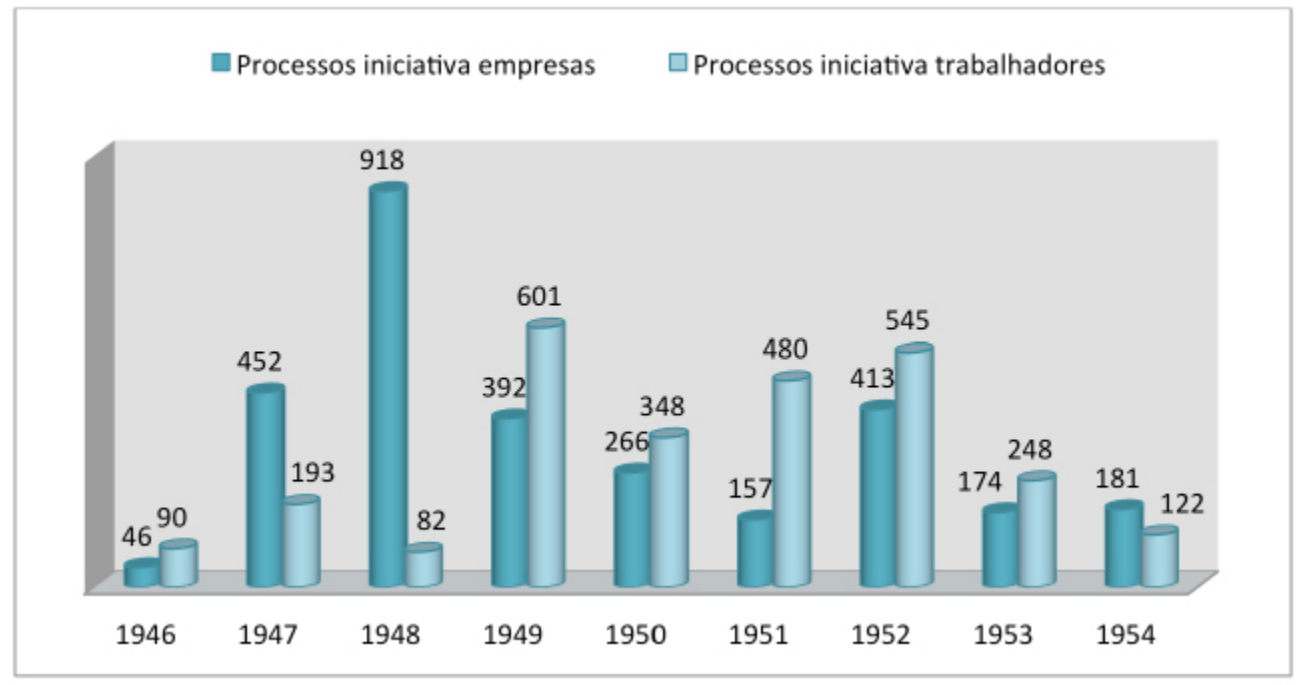

Fonte: Levantamento realizado a partir de processos e atas de audiências da JCJ de São Jerônimo/ MJTRS. 
Nota-se no gráfico um dado até certo ponto surpreendente: ao contrário do que comumente se imagina, as açôes propostas pelo patronato preponderam sobre os processos propostos pelos trabalhadores na Justiça do Trabalho. Em São Jerônimo, o expressivo crescimento dos processos trabalhistas relacionados à mineração entre 1946 e 1948 (especialmente neste último ano) ocorreu devido a uma explosão de reclamatórias propostas pelas duas principais empresas do setor, e não pelos trabalhadores.

A trajetória ascendente, que encontra sua máxima expressão em 1948, já havia começado a se manifestar no ano anterior. Tendo como base as 46 açóes impetradas em 1946, houve um salto para 452 reclamatórias (ou um crescimento de 882\%!). Posteriormente, em 1949, o número de reclamatórias de origem patronal se reduziu a níveis inferiores a 1947, permanecendo em queda, com uma ligeira elevação em $1952 .{ }^{14}$

O segundo ponto a salientar é que o número de processos de iniciativa dos trabalhadores também registra um aumento em 1947, mas volta a cair em 1948, para apresentar, em 1949, crescimento de $633 \%$ em relação ao ano anterior, ultrapassando seis centenas de reclamatórias. Depois, há uma queda, seguida por ligeira recuperação e novamente queda em 1953 e 1954.

Portanto, se o crescimento das açốes segue uma tendência, ele é puxado, até 1948, em termos quantitativos, pelo grande número de reclamatórias propostas pelos patróes. Somente a partir de 1949 é que a quantidade dos processos ajuizados por iniciativa dos operários torna-se mais expressiva. Durante os nove anos da série, os trabalhadores impetram um total de 2.709 reclamatórias, enquanto os patrôes ingressam com 2.999 açóes.

\section{As mineradoras processam os trabalhadores}

Os processos propostos pelos patrôes da mineração apresentam características muito diversas das açóes movidas pelos trabalhadores do setor. Enquanto estes últimos buscavam o Judiciário para garantir uma miríade de direitos (com processos em sua maioria individuais), que vão desde férias e salários atrasados até reintegração, mudança de cargo ou suspensão de puniçóes, as empresas mineradoras quase invariavelmente entravam na Justiça em açôes referentes a abandono do emprego pelo trabalhador. Das 2.999 açóes propostas pelas mineradoras, 2.981 (99,4\%) têm como motivo esse suposto abandono.

\footnotetext{
${ }^{14} \mathrm{Na}$ verdade, a maior relevância quantitativa dos processos patronais já se verifica em 1946, não sendo perceptível no gráfico devido a uma distorção formal na maneira como eles são numerados pela JCJ de São Jerônimo. Até meados de 1947, os processos com mais de um reclamante ou mais de um reclamado eram contabilizados como apenas uma reclamatória. Com a mudança desta sistemática, cada reclamante ou reclamado passou a receber um número individual de processo. Assim, se aplicarmos a 1946 e parte de 1947 a sistemática adotada posteriormente pela Junta, relacionando as açóes ao número de reclamados (no caso das empresas), o número de açóes propostas pelo patronato salta de 46 para 251 em 1946 (ultrapassando, já neste ano, a quantidade de reclamatórias propostas pelos trabalhadores), e de 452 para 652, em 1947.
} 
Eram utilizados dois tipos de processos: por aviso prévio (para empregados não estáveis, com menos de 10 anos de empresa) ${ }^{15}$ ou inquérito para apuração da falta grave de abandono (para empregados estáveis, com mais de 10 anos de empresa). Ambos seguem um padrão comum: a empresa comunica desconhecer o paradeiro de um empregado ou de um grupo de funcionários, eles são convocados por edital, geralmente não comparecem e acabam sentenciados à revelia, ou seja, o julgamento do processo ocorre sem a presença do reclamado (no caso, o trabalhador) ou seu representante legal.

Os casos de inquérito são bem menos numerosos do que os de aviso prévio, e recebem uma atenção maior; neles, geralmente, apresentam-se testemunhas do abandono: o capataz do trabalhador e o apontador (responsável pelo ponto) da mina. Apenas um trabalhador é processado por vez, ao passo que, nas reclamatórias de aviso prévio, dezenas de operários são reclamados ao mesmo tempo. Além disso, nestas últimas, nunca há testemunhas, pois uma cópia do ofício do capataz comunicando à chefia as faltas contínuas parece bastar para comprovar o suposto abandono.

Os resultados também acarretam consequências teoricamente diferentes. Nos processos de inquérito, a sentença favorável à demanda da empresa ("procedente") representa a quebra da estabilidade e a autorização para demissão. Nas reclamatórias por aviso prévio, o "procedente" da Justiça ratifica formalmente a saída do empregado e ainda o obriga ao pagamento do aviso prévio devido ao empregador. Ou seja, o operário sai em dívida. Na prática, porém, as mineradoras apresentavam requisição formal abrindo mão do pagamento do aviso prévio pelo operário pouco depois da sentença. Isto é mais um indício de que a intenção principal do processo era apenas a oficializaçấo do desligamento do empregado.

Os resultados de tais ações foram, no período em tela, amplamente favoráveis aos patrôes. Apenas para dar um exemplo: no ano de 1948, quando as mineradoras entraram com 918 reclamatórias, 912 foram consideradas procedentes, ou seja, com ganho de causa aos patrốes. Destas sentenças, 98,7\% (906) foram por revelia, isto é, o trabalhador não compareceu ao tribunal. Entre as reclamatórias patronais que não obtiveram ganho de causa, os patrôes desistiram em dois casos, em um houve acordo e em apenas três a sentença foi favorável aos trabalhadores. Além disso, do total de ações de 1948, 880 foram por aviso prévio (não estáveis) e 36 de inquérito administrativo por abandono (empregados com estabilidade). Em apenas dois casos, a razão não foi abandono e sim inquérito administrativo por condenação criminal. ${ }^{16}$

\footnotetext{
${ }^{15}$ A estabilidade no emprego ao trabalhador com 10 anos de permanência em uma empresa surgiu no Brasil com a já citada Lei Eloy Chaves, de 1923, que estabeleceu esse direito para os ferroviários. Em 1935, a estabilidade foi estendida aos empregados da indústria e do comércio pela Lei oㅡ 62, e em 1943, com a CLT, a todos os trabalhadores. A estabilidade deixou de existir, na prática, com a criaçáo do Fundo de Garantia por Tempo de Serviço (FGTS), em 1966, na esteira das reformas econômicas do governo Castelo Branco e do Programa de Ação Econômica do Governo (Paeg).

${ }^{16}$ Tratava-se de dois operários com estabilidade que estavam presos na Colônia Penal Daltro Filho, na então vila de Charqueadas, condenados por lesão corporal grave e lesão corporal seguida de morte, e que tiveram sua demissão autorizada à revelia.
} 
Embora 1948 seja o ano com o maior número de açôes patronais, o padrão se mantém por toda a série analisada - há uma preponderância absoluta de sentenças favoráveis aos patrôes. De 1946 a 1954, dos 2.999 processos de iniciativa das empresas, 2.959 (98,6\%) foram considerados totalmente procedentes. $\mathrm{O}$ fenômeno torna-se ainda mais digno de nota se levarmos em conta as açóes movidas pelos trabalhadores consideradas improcedentes, ou seja, nas quais a Junta nega qualquer razão à demanda operária, também dando ganho de causa ao patronato. Durante todo o período, essa situação se repete em 204 processos (7,5\% das açóes propostas pelos trabalhadores ou $3,57 \%$ do total dos processos). Em compensação, o número de demandas dos patrôes consideradas improcedentes é insignificante (10), conforme vemos na tabela 1 .

Tabela 1

Resultados dos processos em mineração - JCJ de São Jerônimo (1946-1954)

\begin{tabular}{|c|c|}
\hline Procedente (iniciativa patrōes) & 2.959 \\
\hline Acordo & 1.207 \\
\hline Procedente (iniciativa trabalhadores) & 694 \\
\hline Arquivado (ausência trabalhadores) & 348 \\
\hline Improcedente (inic. trabalhadores) & 204 \\
\hline Procedente em parte (inic. trabalhadores) & 110 \\
\hline Desistência dos trabalhadores & 96 \\
\hline Desistência dos patrōes & 14 \\
\hline Pedido de demissão homologado & 14 \\
\hline Extinto (incompetência/ilegitimidade) & 15 \\
\hline Improcedente (inic. patrões) & 10 \\
\hline Absolvição de instância & 1 \\
\hline Sem resultado & 36 \\
\hline TOTAL & $\mathbf{5 . 7 0 8}$ \\
\hline
\end{tabular}

Fonte: Levantamento realizado a partir de processos e atas de audiências da JCJ de São Jerônimo/ MJTRS.

Apesar de o número de reclamatórias patronais ser apenas ligeiramente superior ao das açôes de iniciativa dos trabalhadores (2.999 contra 2.709), no conjunto dos nove anos, a desproporção nos resultados é amplamente favorável ao patronato. Além disso, 99,42\% (2.942) das sentenças favoráveis aos patróes em reclamatórias interpostas por eles mesmos ocorreram à revelia, ou seja, o trabalhador não compareceu mesmo após a convocação (geralmente por edital). Os mesmos resultados podem ser analisados visualmente no gráfico 3. Ele demons- 
tra que os resultados mais significativos, em termos proporcionais, durante o período, são justamente as sentenças totalmente procedentes conferidas ao patronato e os acordos, nas açóes interpostas pelos operários.

Gráfico 3

Principais resultados dos processos referentes à mineraçáo na JCJ de Sáo Jerônimo (1946-1954)

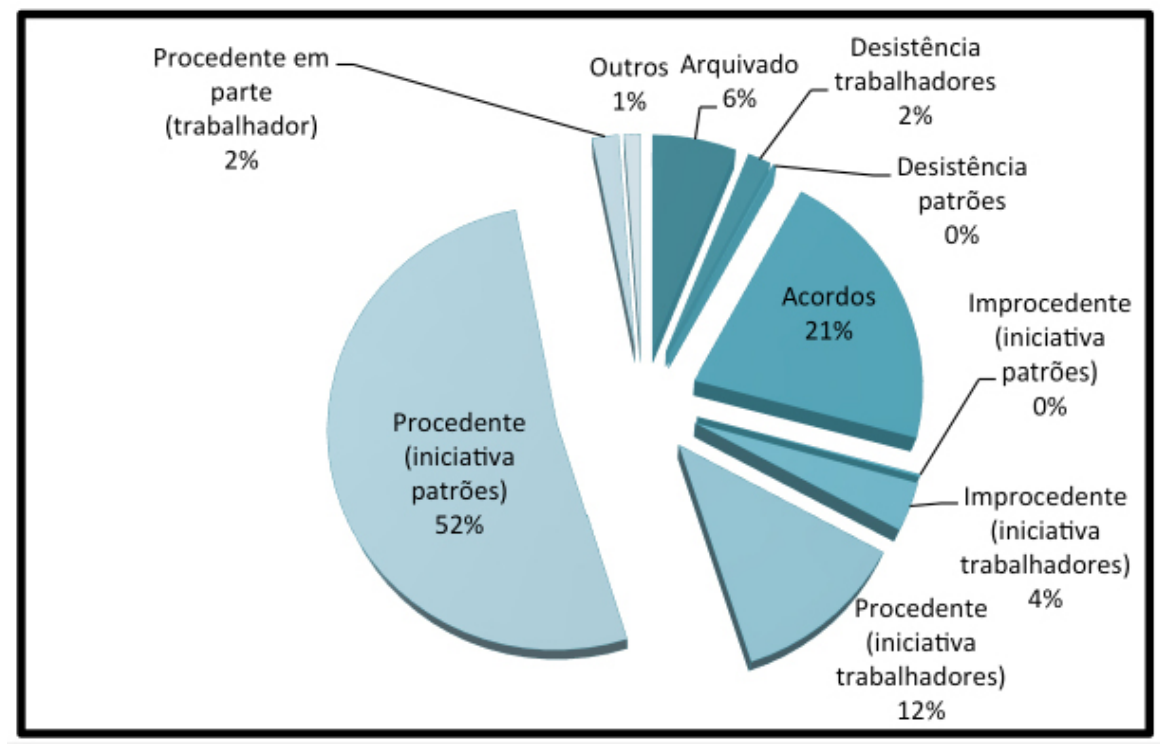

Fonte: Levantamento realizado a partir de processos e atas de audiências da JCJ de São Jerônimo/ MJTRS.

Portanto, mais da metade dos resultados de todos os processos impetrados na Junta de Sáo Jerônimo obteve o resultado "procedente" para as reivindicaçôes patronais. Se somarmos essas evidentes vitórias judiciais das empresas às sentenças nas quais as açóes propostas pelos trabalhadores foram consideradas improcedentes, o gráfico ficaria assim: 


\section{Gráfico 4}

\section{Resultados favoráveis ao patronato nos processos referentes à mineraçáo na JCJ de Sáo Jerônimo (1946-1954)}

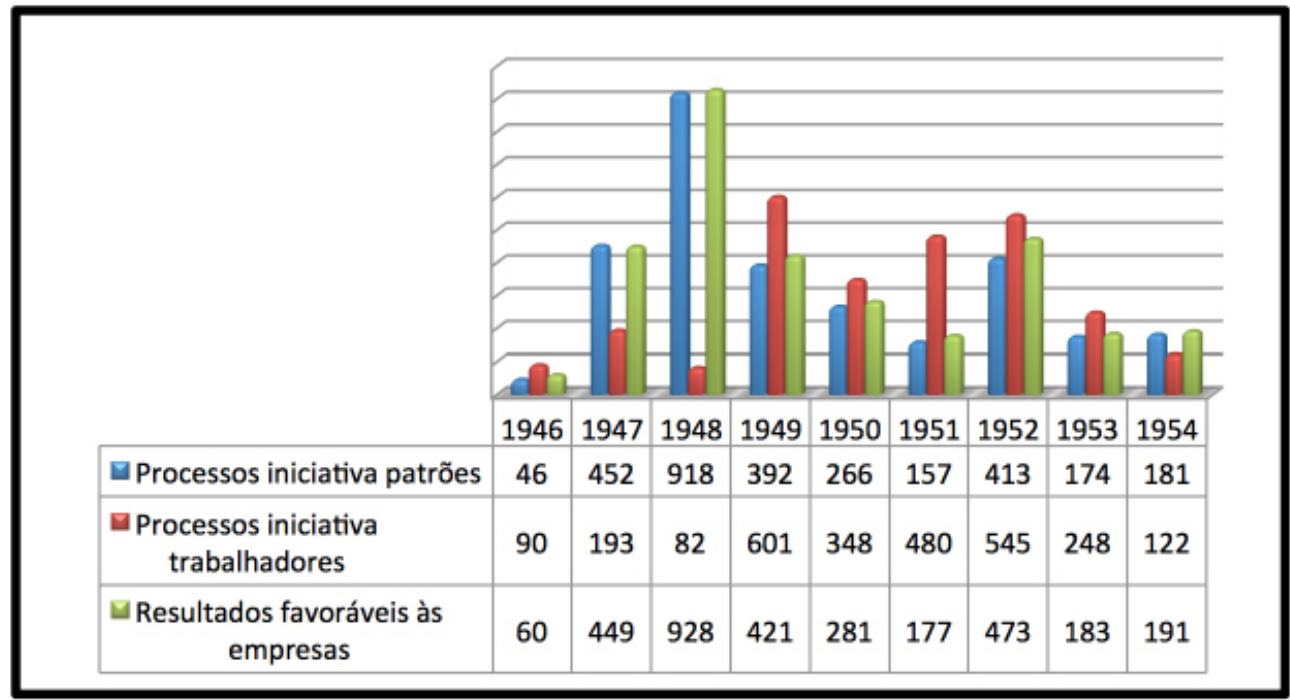

Fonte: Levantamento realizado a partir de processos e atas de audiências da JCJ de São Jerônimo/ MJTRS.

Como se observou, os resultados para os patróes da mineração na Justiça do Trabalho local foram largamente favoráveis, superiores inclusive ao próprio total de reclamatórias propostas por eles mesmos, se somados às sentenças desfavoráveis aos trabalhadores em açóes movidas por estes. Em quase todos os anos (com exceção apenas de 1947, por pequena margem), os resultados favoráveis ao patronato ultrapassam o número de processos de iniciativa das empresas.

Por outro lado, a preponderância absoluta de processos patronais referentes a abandono do emprego pelos trabalhadores desperta dúvidas. Chama a atenção que, de 1946 a 1954, foram oficializadas demissóes de 3.321 trabalhadores, 97\% destes não estáveis. Isto representa cerca de $40 \%$ do total da força de trabalho empregada das minas em 1943. Parece crível que quase a metade dos trabalhadores da mineração tenha, em poucos anos, simplesmente sumido sem deixar vestígios (já que a maior parte das sentenças era por revelia, ou seja, o operário não era localizado)?

Alguns raros casos nos quais os trabalhadores processados compareceram às audiências podem nos ajudar a compreender melhor tal questão. Geralmente, estes operários alegavam estar doentes ou mesmo terem sido impedidos de trabalhar pela empresa depois de algum eventual afastamento temporário. Em uma situação específica, o empregado que pretensamente teria abandonado o emprego compareceu à Justiça e alegou que o médico da empresa rasgou o atestado assinado por ele mesmo depois que esse não foi aceito pela Companhia. Examinemos melhor esse relato. 
Em inquérito administrativo instaurado em meados de 1947, o tocador de carros Antônio Pereira Nunes ${ }^{17}$ admitiu que realmente havia abandonado o serviço e ido procurar emprego em Porto Alegre, mas afirmou que isso teria acontecido porque estava doente e a Companhia Carbonífera Minas de Butiá (CCMB) não teria aceitado o atestado fornecido pelo médico da empresa. A consulta havia ocorrido ao fim de uma licença anterior de 90 dias para tratamento médico. Examinado, Nunes teria conseguido "baixa" por mais 15 dias. Porém, a empresa entrara em contato com o médico e mandado o empregado de volta. Quando Nunes retornou ao consultório, o médico teria rasgado o original. Com isso, o mineiro ficou sem salário doença e sem condiçôes de pedir a aposentadoria. Suas alegaçôes não tiveram sucesso. $\mathrm{O}$ médico sustentou datas diferentes para a emissão do atestado, a JCJ considerou que o trabalhador havia falsificado o documento e julgou o processo patronal procedente, autorizando a demissáo.

Em outro caso, ocorrido no mês de abril de 1948, Manoel José Mota compareceu à audiência do processo em que era acusado de abandono do emprego pela CCMB. Alegou que, desde janeiro de 1947, quando havia tido o salário doença suspenso, trabalhava como vendedor ambulante em frente ao escritório da empresa, nos dias de pagamento. Poderia ter sido facilmente localizado, portanto. Não adiantou. Teve seu abandono oficializado, assim como outros 27 operários naquele dia. ${ }^{18}$

Com a mesma sorte, em janeiro de 1949, Manoel Pedro Simóes Pires entrou com um processo por reintegração contra a empresa alegando ter sido condenado injustamente em uma ação patronal anterior por aviso prévio. Analfabeto, contou ter sofrido um acidente em 1944 e que, depois disto, a empresa havia se recusado a dar-lhe serviço. Os detalhes do depoimento não foram transcritos, por decisão do juiz, e o pedido foi considerado improcedente, por prescrição (já haviam se passado dois anos da sentença referente à ação patronal). ${ }^{19}$

Outros acabaram se dando melhor. Em 27 de junho de 1950, Adriovano Albuquerque foi até a audiência em que era acusado de abandono e a empresa desistiu de demiti-lo. ${ }^{20} \mathrm{O}$ mesmo fez Antônio de Freitas Xavier em março de 1951, munido de atestado médico, conseguindo assim ser poupado. ${ }^{21} \mathrm{O}$ caso mais interessante, porém, aconteceu com Ludoviku Loba, processado em novembro de 1948.

Operário desde 1945, Ludoviku náo compareceu à audiência na qual foi condenado a pagar o aviso prévio à Companhia Estrada de Ferro e Minas de Sáo Jerônimo (CEFMSJ) por abandono. Porém, entrou com um recurso logo depois, alegando que, doente, não havia conseguido tomar o ônibus que ligava a vila de Arroio dos Ratos até a cidade de Sáo Jerônimo a tempo. Assim, só teria chegado ao local depois de a audiência ter terminado. Ludoviku apresentou atestado médico e ganhou o recurso, que lhe daria direito a novo julgamento.

\footnotetext{
${ }^{17}$ Processo 183/47. CD Processos Trabalhistas de São Jerônimo/RS (1938/1947). Coleção Acervos. MJTRS.

${ }^{18}$ Processo 95 a 122/48. Livros de atas e audiências da JCJ São Jerônimo 1948. MJTRS.

${ }^{19}$ Processo 04/49. Livros de atas e audiências da JCJ Sáo Jerônimo 1949. MJTRS.

${ }^{20}$ Processo 320 a 340/50. Livros de atas e audiências da JCJ São Jerônimo 1950. MJTRS.

${ }^{21}$ Processo 27 a 61/51. Livros de atas e audiências da JCJ São Jerônimo 1951. MJTRS.
} 
A empresa, no entanto, resolveu recorrer ao Tribunal Superior do Trabalho (TST). ${ }^{22}$ Ludoviku contra-atacou. Assistido pelo advogado do Sindicato, entrou em 1949 com uma nova reclamatória pedindo aviso prévio e indenização por despedida injusta, ${ }^{23}$ enquanto o recurso da empresa tramitava no TST. O processo no tribunal superior se arrastou e atrasou o outro, que acabou sendo julgado só em janeiro de 1950. Somente nesse momento Ludoviku foi ouvido. Ele declarou que não havia abandonado o serviço, e que, pelo contrário, teriam lhe negado trabalho sistematicamente. Depois de um período afastado por doença, havia se reapresentado aos patrôes, mas fora transferido de um setor para outro, sem funçáo. Compareceu na boca do poço por 25 dias, "tendo os chefes dito todos os dias que não havia serviço para ele". ${ }^{24} \mathrm{Na}$ Justiça, apresentou uma testemunha que confirmava o que dizia. A JCJ considerou seu processo como procedente em parte, condenando a empresa a pagar o aviso prévio e metade da indenização (num total de Cr\$2.481,20 — ou mais de seis vezes o salário mínimo da época - Cr\$380,00).

O que esses processos deixam entrever é que o "abandono" podia significar, na verdade, uma demissáo informal por parte das empresas ou uma recusa em dar serviço a empregados doentes. Controlando os serviços médicos, as companhias limitavam a distribuição de atestados e dificultavam ao máximo a concessão de salário doença. Sem saúde e sem dinheiro, muitos trabalhadores eram relegados ao limbo por capatazes e chefes de turno, permanecendo assim meses a fio. Ou, pode-se supor, pela quantidade de demissóes já mencionada, eram simplesmente dispensados "de boca", sem aviso prévio ou indenização e, no mundo da vila-fábrica, onde tudo, desde o armazém até as moradias, era das empresas, nem todos tinham outra possibilidade a não ser juntar as trouxas, a mulher e os filhos e procurar melhor sorte em outras paragens. Lembro que os casos citados acima são exceçóes: a maioria dos trabalhadores processados por abandono não aparecia na Junta para se defender e os processos acabavam sendo considerados procedentes por revelia.

A prosperar esta hipótese, o que ocorria era, muito mais do que uma "ficção jurídica", como aventamos antes, um "ato mágico de nomeaçáo" (no sentido pensado por Bourdieu). ${ }^{25} \mathrm{O}$ empregado doente ou dispensado informalmente era transformado em sujeito de um ato passível de ser repreendido juridicamente e que justificava seu desligamento, agora formal, da empresa mineradora. Entrando na Justiça contra os empregados, os patróes guarneciam-se contra futuros processos e oficializavam os desligamentos, eximindo-se de qualquer indenização.

\footnotetext{
${ }^{22}$ Processo 847 a 860/48. Livros de atas e audiências da JCJ São Jerônimo 1948. MJTRS.

${ }^{23}$ Processo 21/49. Livros de atas e audiências da JCJ São Jerônimo 1949. MJTRS.

${ }^{24}$ Audiência em 31-1-1950. Sentença em 10-2-1950. Processo 21/49. Livros de atas e audiências da JCJ São Jerônimo 1949. MJTRS.

${ }^{25}$ Para Bourdieu, o "direito é a forma por excelência do discurso atuante, capaz, por sua própria força, de produzir efeitos. Não é demais dizer que ele faz o mundo social, mas com a condição de não se esquecer que ele é feito por este". O ato de nomeação é um "ato de força simbólica que só é bem-sucedido porque está bem fundado na realidade". BOURDIEU, Pierre. A força do direito: elementos para uma sociologia do campo jurídico. In: BOURDIEU, Pierre. O poder simbólico. Rio de Janeiro: Bertrand Brasil, 2007. p. 237-239.
} 


\section{Quando a iniciativa era dos trabalhadores}

Se as reclamatórias patronais foram, em absoluta maioria, provocadas por "abandono", as razóes se evidenciam muito mais numerosas e diversas nas açóes dos trabalhadores. Além disso, como foi dito, eles não obtêm o mesmo sucesso na acolhida de suas reivindicaçóes que os patróes. Para os trabalhadores, o número de processos em que há algum ganho foi sempre inferior ao de reclamatórias propostas.

No entanto, o saldo para os operários dos resultados das açóes na Junta de São Jerônimo não foi desprezível. Pelo contrário. Depreende-se do gráfico 5 a ideia de que um trabalhador tinha chance bastante razoável de sair da Junta com algum ganho, mesmo que bem inferior à sua demanda inicial. Basta observar a coluna verde, que representa a soma das sentenças totalmente favoráveis aos trabalhadores e das totalmente desfavoráveis aos patróes, bem como dos acordos e das decisóes apenas parcialmente favoráveis às demandas dos operários.

\section{Gráfico 5}

\section{Resultados dos processos referentes à mineraçáo para os trabalhadores na JCJ de São Jerônimo (1946-1954)}

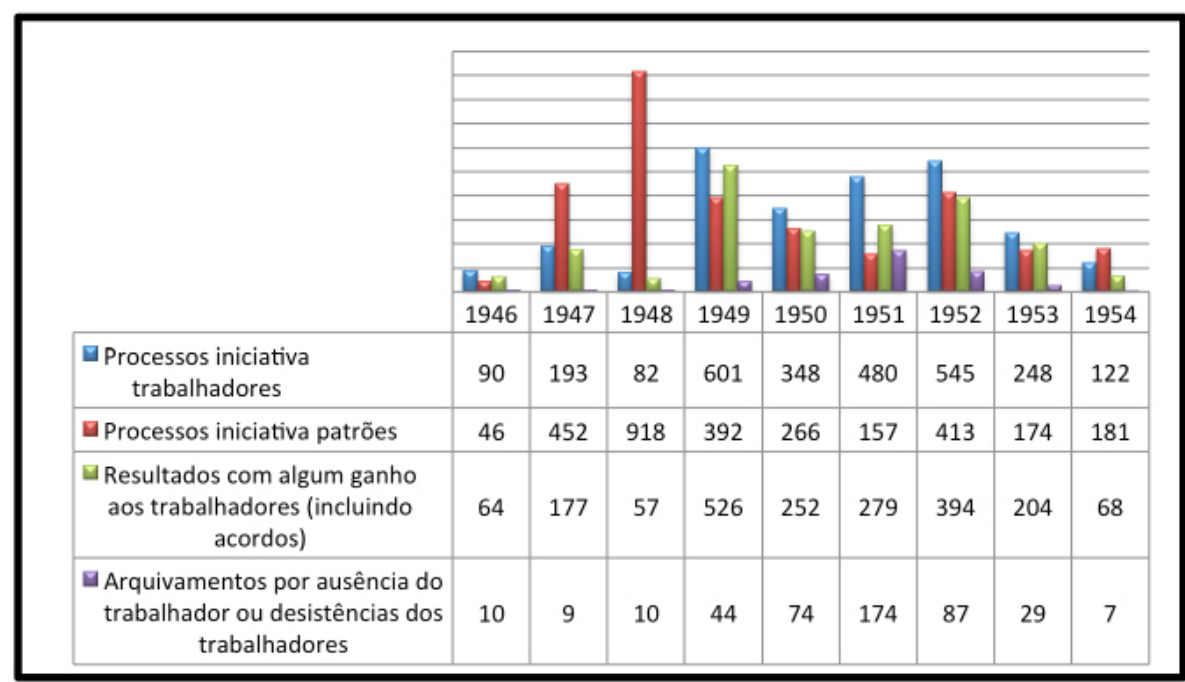

Fonte: Levantamento realizado a partir de processos e atas de audiências da JCJ de São Jerônimo/ MJTRS.

Esta constatação é reforçada se observamos as colunas que representam os arquivamentos (decorrentes de ausências) e as desistências em processos movidos por trabalhadores. Há um índice significativo de arquivamentos e desistências, decorrentes da própria insegurança estrutural da situação do trabalhador, das pressóes patronais e das dificuldades de locomoção e distância das vilas mineiras da sede da Junta.

Os resultados que representam algum ganho aos trabalhadores englobam três situa- 
çôes diferentes. Há resultados totalmente favoráveis, quando a demanda dos trabalhadores é plenamente atendida (processos de iniciativa dos operários com sentença procedente) ou quando a demanda dos patrôes é totalmente rejeitada (processos de iniciativa do patronato com sentença improcedente). A segunda situação ocorre nas sentenças procedentes em parte em ações de iniciativa dos trabalhadores, quando o mineiro tem uma parcela de sua petição inicial considerada válida. E, por fim, nos acordos, o processo termina por um acerto entre patróes e empregados, cujos termos variam entre a aceitaçáo quase completa das demandas até ganhos (simbólicos ou materiais) bem inferiores. Vamos ver, entâo, de que forma estas três situaçôes se combinam.

\section{Gráfico 6}

\section{Resultados dos processos referentes à mineraçáo para os trabalhadores na JCJ de Sáo Jerônimo (1946-1954) — processos trabalhistas com algum ganho para os trabalhadores}

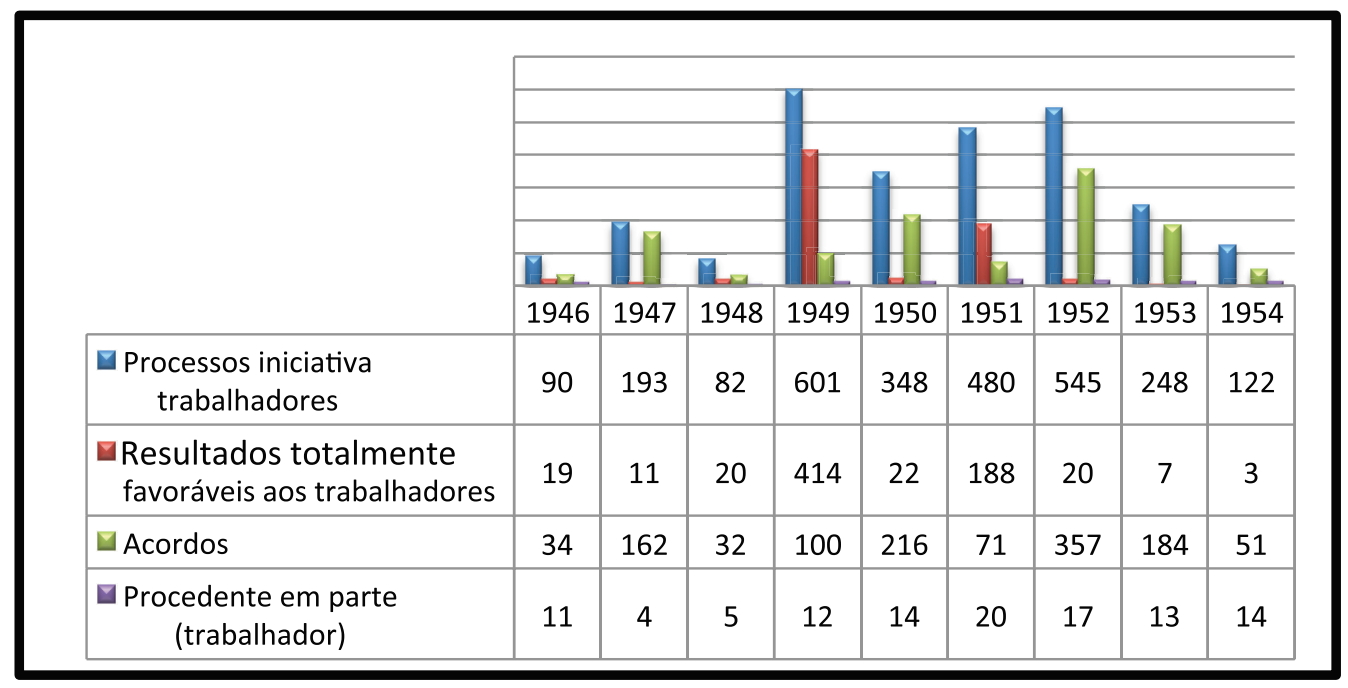

Fonte: Levantamento realizado a partir de processos e atas de audiências da JCJ de São Jerônimo/ MJTRS.

Com exceção de 1949 e parcialmente em 1951, a soma de sentenças procedentes para os trabalhadores e improcedentes para os patrōes (coluna vermelha) é insignificante em face da quantidade de processos propostos. Durante os nove anos pesquisados, houve 694 sentenças procedentes em reclamatórias propostas pelos trabalhadores. Destas, 412 ocorreram em 1949 e 185, em 1951. Ou seja, 86\% das sentenças nas quais o Judiciário trabalhista atendeu totalmente a petição inicial feita pelos operários na série pesquisada foram referentes a processos instaurados em 1949 e 1951.

As sentenças procedentes em parte nunca chegaram a ultrapassar o patamar das duas dezenas. $\mathrm{O}$ resultado mais expressivo para os trabalhadores, em termos numéricos, foram os 
acordos. Das 2.709 açóes que surgiram por iniciativa dos trabalhadores da mineração entre 1946 e 1954, 1.207 resultaram em acordos. Esse conjunto representa 44,55\% das açóes propostas pelos operários e $21,14 \%$ do total de reclamatórias. E a situação de excepcionalidade de 1949 e de 1951 torna isto ainda mais claro. Se eliminarmos estes dois anos da contagem, o índice de acordos sobe para 63,6\%. Se em 1946 a percentagem de acordos já alcançava $38 \%$, ou seja, um quarto de todos os processos propostos na JCJ por trabalhadores na mineração, em alguns anos, como 1953, os acordos chegaram a três quartos (74\%) das ações dos operários.

Na década de 1950, no Rio Grande do Sul, aparentemente, boa parte dos trabalhadores da mineração já ingressava com um processo trabalhista visando fechar um acordo. Vários indícios corroboram essa hipótese: os processos tornam-se cada vez mais curtos, com no máximo uma audiência onde as partes sequer são ouvidas, pois já manifestam de antemão a sua intenção de fazer acordo. Em muitos, sequer é produzida uma ata de audiência, apenas preenchido o formulário padronizado "termo de conciliação". Em outros, os empregados entram com uma reclamatória e nem compareceram ao Tribunal, apenas comunicando à Justiça antes da primeira audiência que já haviam fechado o acerto com os patróes. Em 1953 e 1954, 67 trabalhadores não apareceram nas audiências da Justiça do Trabalho em ações propostas por eles mesmos, mas houve apenas 23 arquivamentos. Em todas as outras, a Justiça homologou acordos feito extrajudicialmente pelas partes, o que dispensava a presença de patróes e empregados no Tribunal.

Em relações às razóes que levaram os mineiros a recorrer à JCJ, os processos propostos pelos trabalhadores apresentaram, como já mencionamos, uma grande variedade de reivindicações. Além disso, havia ações com diversas motivações, principalmente no final da série analisada, provindas de trabalhadores em processo de desligamento da relação de emprego. Isto, aliado ao crescimento no número de acordos já assinalado, evidencia que, com o passar dos anos, o operário tendia a elencar o maior número possível de reivindicaçóes na sua reclamatória não na expectativa de ganhar todas, mas sim de jogar para o alto o valor do acordo provável. ${ }^{26}$

O fichamento e a tabulação dos dados referentes às 2.709 reclamatórias propostas pelos trabalhadores entre 1946 e 1954 permitiram produzir uma tabela com as demandas dos operários e sua percentagem diante do conjunto total. Apresento um resumo dessa tabela, com as 10 principais reivindicaçóes dos trabalhadores do ponto de vista quantitativo.

\footnotetext{
${ }^{26}$ Neste levantamento quantitativo trabalhei com dois tipos básicos de documentos, como já mencionado: processos completos dos anos de 1946 e 1947; e as atas das audiências das açóes de 1948 a 1954. Enquanto os processos completos não oferecem dificuldades para se identificar as demandas dos trabalhadores, pois incluem a petição inicial ou termo de reclamação, as atas das audiências nem sempre são claras neste sentido, em especial nas reclamatórias que têm tramitação curta, seja por arquivamento, acordo ou desistência. Além disso, os secretários da Junta, a quem cabia redigir as atas, muitas vezes não obedeciam ao mesmo critério ou nomenclatura para identificar a demanda (além de haver frequentes erros na numeração dos processos). Não foi possível apurar a razão de um número pequeno de açôes posteriores a 1948, pois a JCJ sequer criou atas de audiências preliminares para elas, apenas termos indicando acordo ou arquivamento.
} 
Tabela 2

Reclamaçóes constantes nos processos propostos por trabalhadores na JCJ de Sáo Jerônimo (1946-1954)

\begin{tabular}{|l|c|r|}
\hline RECLAMAÇÓES & RECLAMATÓRIAS & \multicolumn{1}{c|}{$\%$} \\
\hline 1. Descanso semanal remunerado & 1.164 & $\mathbf{4 2 , 8 2}$ \\
\hline 2. Horas extras & 753 & $\mathbf{2 7 , 7 0}$ \\
\hline 3. Questôes salariais (*) & 616 & $\mathbf{2 2 , 6 6}$ \\
\hline 4. Férias & 411 & $\mathbf{1 5 , 1 2}$ \\
\hline 5. Gratificações ou percentagens & 364 & $\mathbf{1 3 , 4}$ \\
\hline 6. Indenizações (tempo serviço ou despedida) & 281 & $\mathbf{1 0 , 3 3}$ \\
\hline 7. Aviso prévio & 238 & $\mathbf{8 , 7 6}$ \\
\hline 8. Suspensão & 151 & $\mathbf{5 , 5 5}$ \\
\hline 9. Seguro/salário doença & 92 & $\mathbf{3 , 3 8}$ \\
\hline 10. Descontos & 63 & $\mathbf{2 , 3 2}$ \\
\hline
\end{tabular}

Fonte: Levantamento realizado a partir de processos e atas de audiências da JCJ de São Jerônimo/ MJTRS.

(*) Inclui salários atrasados, saldo de salários, diferenças, salário mínimo, aumento ou redução de salários.

A reivindicação "descanso semanal remunerado" aparece em 42,82\% das reclamatórias propostas pelos trabalhadores, ou seja, quase a metade dos processos. Isto se torna ainda mais digno de nota ao pensarmos que ela só começou a aparecer a partir de 1949, quando foi promulgada a Lei no 605, que dispóe sobre este direito. Na verdade, como vemos no gráfico 7, tal demanda se concentra, proporcionalmente, nos três anos seguintes à promulgação da lei.

Da mesma forma, o segundo item da lista, "horas extras", e o quarto, "férias", têm relação com discussóes e modificações das legislações respectivas no período, configurando-se como tentativas dos trabalhadores de fazerem cumprir o arcabouço legal ignorado pelos patróes. A carga horária dos trabalhadores da mineração no subsolo havia sido diminuída de oito para seis horas com o advento da Consolidação das Leis do Trabalho (CLT), em 1943. No entanto, as burlas a esta legislação eram constantes, em especial, por meio da transferência de funções entre os empregados. Em relação às férias, há uma alteração provocada pela Lei no 816, de setembro de 1949 , que aumentou o prazo de duração das férias. ${ }^{27}$ As demandas por hora extra apresentam dois picos, um em 1947 e outro em 1952, enquanto as reclamatórias pedindo o pagamento de férias são mais frequentes em 1950 e no fim da série (1954).

\footnotetext{
${ }^{27}$ Sobre as mudanças na legislação de férias e descanso semanal remunerado no período, ver SÜSSEKIND, Arnaldo. Duração do trabalho e repousos remunerados. Rio de Janeiro: Freitas Bastos, 1950.
} 
Vistos em conjunto, os gráficos referentes ao descanso semanal remunerado e às horas extras mostram que as demandas de um direito crescem quando as do outro baixam, e vice-versa. Assim, é exatamente no intervalo em que cresce a proporção de reclamatórias por descanso semanal remunerado que diminui a de açôes por hora extra, o que talvez indique a importância e a premência da luta pelo pagamento do primeiro direito logo em 1949 e nos dois anos seguintes. Isto pode indicar uma troca de informaçóes entre operários, sindicato e advogados trabalhistas em relação a demandas com maior possibilidade de acolhida junto ao JCJ em cada período.

O terceiro item em frequência da lista — questôes salariais — abrange um leque amplo de situaçóes, mas essas não têm aparentemente relação tão direta com as leis recém-aprovadas quanto as demandas examinadas anteriormente. Ele diz respeito ao descumprimento, parcial ou integral, de um elemento básico do contrato de trabalho: o pagamento de salário. Por afinidade, resolvi incluir neste item desde o atraso no pagamento até saldos de salários devidos depois de demissóes, ou diferenças salariais às quais os empregados da mineração faziam jus, ou até o pagamento do salário mínimo para menores. De qualquer forma, como vemos no gráfico 7 , todas as cinco reivindicaçôes mais frequentes nas açôes propostas pelos trabalhadores dizem respeito a diferenças salariais ou a direitos previstos em lei, mas não respeitados.

\section{Gráfico 7}

As cinco reivindicaçóes mais frequentes dos processos propostos por trabalhadores na JCJ de São Jerônimo (\% do total de açóes)

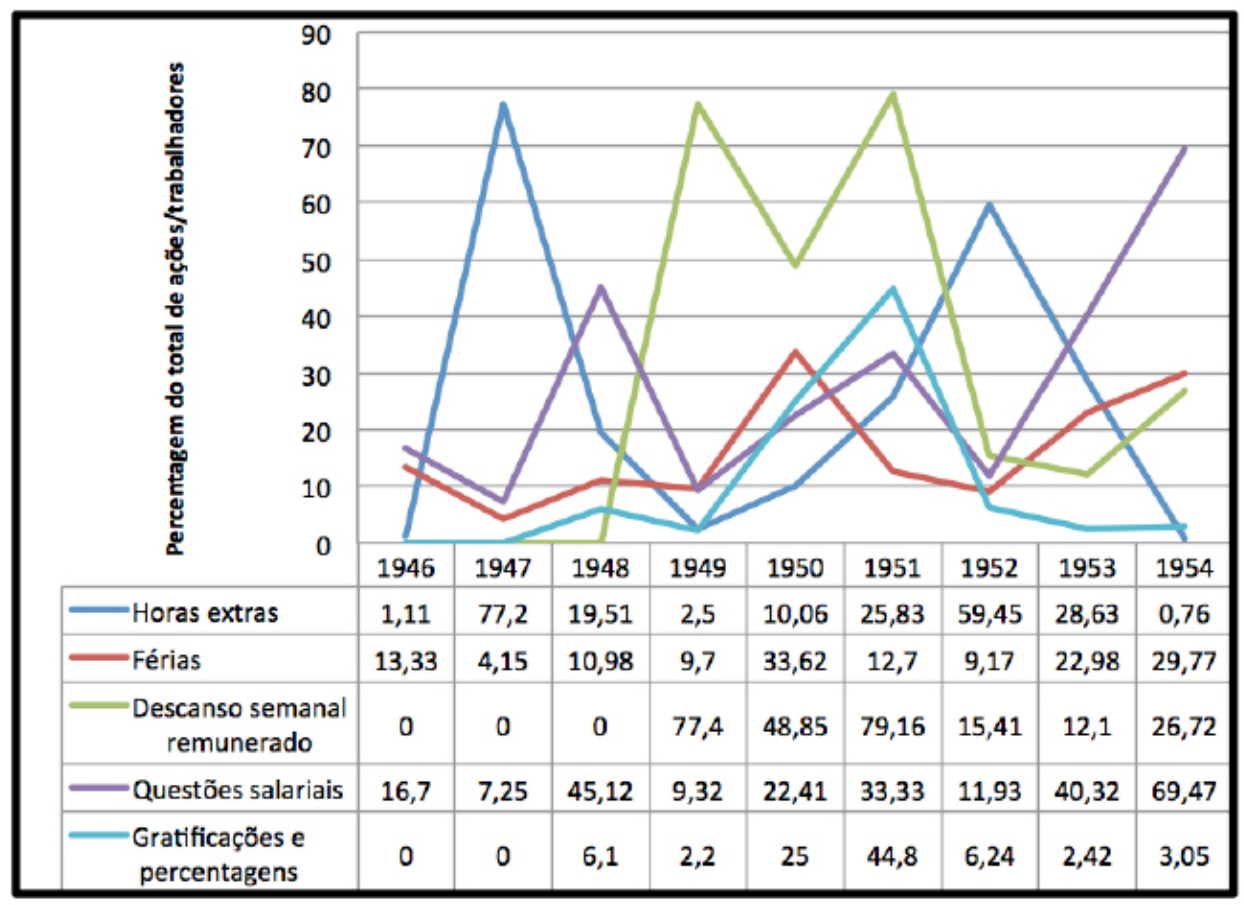

Fonte: Levantamento realizado a partir de processos e atas de audiências da JCJ de São Jerônimo/ MJTRS. 
Algumas outras demandas, apesar de bem menos frequentes, merecem nossa atenção. As reclamatórias em relação a salário doença são esperadas, dentro de uma categoria submetida a função notoriamente insalubre. Vale lembrar também que a concessão de salário doença dependia do atestado fornecido pelo médico da empresa, o que era negado em diversas ocasiôes, sendo objeto de diversas reclamaçôes nos processos, como já apontamos ao apresentar o inquérito administrativo do tocador Antônio Nunes.

Outro dado relevante que se torna perceptível a partir da análise quantitativa dos processos é a participação de advogados nas açôes, a despeito de uma das inovaçôes importantes da Justiça do Trabalho, quando de seu surgimento, ser a possibilidade de o trabalhador (sindicalizado) poder fazer e defender sua reivindicação pessoalmente, sem a presença de um mediador. ${ }^{28}$ Apesar disso, boa parte das reclamatórias propostas pelos trabalhadores foi realizada por meio de advogados, e, mais significativo ainda, aparentemente através do Sindicato dos Trabalhadores na Indústria em Extração do Carvão de São Jerônimo (o sindicato dos mineiros de carvão). $\mathrm{O}$ órgão de representação dos trabalhadores se faz presente explicitamente na maioria absoluta das açôes, como vemos no gráfico 8 , que inclui o somatório das reclamatórias propostas pelos operários entre 1948 e 1954 (período na amostra de maior preponderância das açôes de iniciativa dos mineiros).

\section{Gráfico 8}

\section{Trabalhadores da mineraçáo nas audiências da JCJ de Sáo Jerônimo em açóes propostas contra os patróes (1948-1954)}

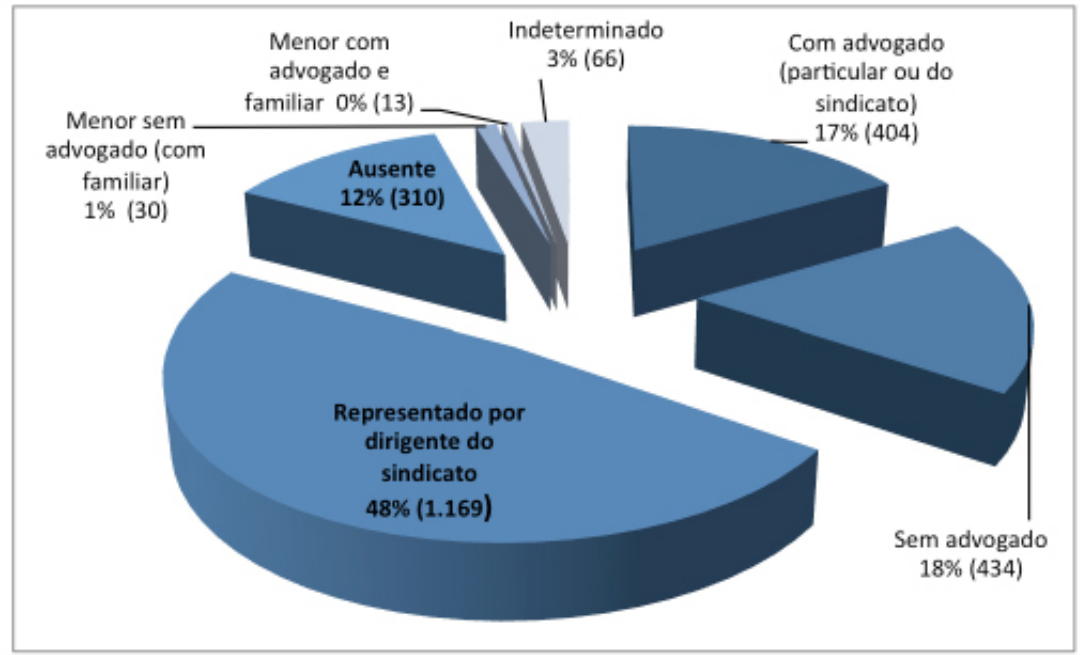

\footnotetext{
${ }^{28}$ Princípio da informalidade, segundo o qual "o empregado estava autorizado a comparecer pessoalmente (sem advogado) ao juízo competente e ali fazer uma 'reclamação' verbal (oralmente) que seria distribuída e, marcada a audiência, só então era tomada a termo por um servidor do juízo”. Nesses procedimentos estão duas 'marcas' originais do processo trabalhista: a reclamação direta do autor (sem advogado) e a oralidade. LAGE, Telma; CARDOSO, Adalberto. As normas e os fatos: desenho e efetividade das instituiçóes de regulação do mercado de trabalho no Brasil. Rio de Janeiro: FGV, 2007. p. 102.
} 
Fonte: Levantamento realizado a partir de processos e atas de audiências da JCJ de São Jerônimo/ MJTRS.

Como não foi possível definir em todas as reclamatórias se o advogado era ou não do Sindicato, pois boa parte das atas omite essa indicação, optei por não tabular este dado. Portanto, as indicaçóes referentes aos advogados também incluem as representações por advogados do sindicato. Embora incompletas, tais informaçóes ratificam o alto grau de organização dos mineiros e indicam desde já a opção do órgão sindical em utilizar a via legal como instrumento para garantia de cumprimento de direitos.

\section{Considerações finais}

O papel do sistema legal na formação do operário brasileiro e na conformação histórica das relaçôes de trabalho do país é um tema fértil. John French defendeu que o processo de criação do aparato legal de proteção ao trabalhador no país (incluindo a Justiça do Trabalho) foi marcado pela ineficácia, negligência e omissão governamentais. Coube aos operários subverter essas condiçóes por meio da luta para tornar realidade direitos legais criados supostamente para nunca serem cumpridos ("um ideal imaginário"). Conforme o brasilianista, a lei e os operários teriam sido usados no país por militantes como forma de mobilizar trabalhadores comuns, apropriando-se dos conceitos jurídicos e construindo uma "consciência jurídica de classe". ${ }^{29}$

Angela de Castro Gomes, por outro lado, considera que a visão de French, ao resumir a ação política a uma tentativa de "ludibriar os trabalhadores", não levaria em conta interesses e projetos políticos dos atores, relacionados à "importância da existência das leis e da possibilidade e capacidade da população delas se apropriar para defender e expandir direitos". ${ }^{30} \mathrm{Na}$ mesma linha, Sidney Chalhoub e Fernando Teixeira da Silva consideram que a interpretação do autor norte-americano, de que as leis trabalhistas foram feitas para nunca serem implementadas, de fato "reafirma o pressuposto de que no Brasil as leis consistem na formulação de situações desejáveis, ideais, que todos sabem impossíveis de atingir, mas reconhecem necessárias para 'civilizar' os costumes". ${ }^{31}$ Por isso, defendem um maior número de estudos empíricos para aclarar melhor a função das normas legais no processo histórico brasileiro, em especial, em relação à Justiça do Trabalho.

\footnotetext{
${ }^{29}$ FRENCH, John. Afogados em leis. São Paulo: Perseu Abramo, 2002. A expressão citada pelo autor é de Aziz Simão.

${ }^{30}$ GOMES, Angela de Castro. Reflexóes em torno do populismo e do trabalhismo. Revista Varia Historia, Belo Horizonte, n. 28, p. 61-62, 2002.

${ }^{31}$ CHALHOUB, Sidney; SILVA, Fernando Teixeira da. Sujeitos no imaginário acadêmico: escravos e trabalhadores na historiografia brasileira desde os anos 1980. Cadernos AEL, Campinas, v. 14, n. 26, p. 39, 2009.
} 
Porém, a questão mais relevante parece ser menos a compreensão das diferentes intencionalidades e motivaçôes iniciais dos atores que produziram a chamada "legislação social" no Brasil, em especial durante o período varguista, do que a fertilidade de significados e circunstâncias que adveio de sua implementação prática. A norma legal trabalhista, em sua ideologia e em sua lógica, impregnada de valores como o da harmonia de classes corporativista, sofreu a pressão e a ação de trabalhadores, empresários e dos próprios mediadores do direito, que a recriaram em suas práticas e conforme seus interesses.

Ao examinar a série de processos relacionados à mineração do Rio Grande do Sul nos nove anos imediatamente posteriores à Segunda Guerra Mundial e logo após a instalação da Justiça do Trabalho na região de São Jerônimo, pode-se concluir que o recurso ao tribunal trabalhista foi se tornando cada vez mais frequente entre os mineiros de carvão. Esse fenômeno revela um aprendizado, por parte dos trabalhadores, da utilizaçáo dos instrumentos legais, fazendo com que categorias e noçóes estruturadoras do Judiciário trabalhista e do direito do trabalho fossem componentes importantes na formação da consciência dos mineiros, em conjunto com outros fatores, como a experiência cotidiana do trabalho, a vida comunitária e a militância sindical e política.

O levantamento mostra uma significativa relação entre as legislaçôes recém-promulgadas (e não cumpridas) e o número de reclamatórias operárias. O destaque é a predominância de açôes pedindo pelo descanso semanal remunerado, previsto em legislação de 1949, que sofreu enorme resistência de amplas parcelas do patronato (não só das mineradoras) ${ }^{32}$ para ser efetivamente implementado no Brasil.

Em contraste, são dignos de nota também a ampla utilização patronal da Justiça do Trabalho e os resultados positivos que os empresários obtêm nas açóes contra os operários. O artifício de propor um grande número de processos por suposto abandono de emprego indica uma estratégia patronal no sentido de utilizar a nascente legislação "social" e as instituiçóes que a garantiam, em especial a Justiça do Trabalho, a seu favor. Sugere, ainda, uma relativa aceitaçáo das "novas regras do jogo", mesmo diante da resistência manifesta a diversos aspectos das novas leis.

O exame dos processos da JCJ de São Jerônimo nos faz ver ainda um outro ator social - para além dos mineiros de carvão e das mineradoras. Esse ator, em processo de afirmação na sociedade brasileira, era a própria JCJ, ou a Justiça do Trabalho. Cada sentença, cada processo são, antes de tudo, uma afirmação social do próprio poder de um ramo recém-nascido (à época) do Judiciário de intervir nas relaçôes de trabalho, ratificando ou suspendendo demissôes, avalizando ou desautorizando puniçôes, com base numa concepção particular de sociedade. O crescimento do número de reclamatórias reflete também a construção, por

\footnotetext{
32 Sobre a luta para a implementação do descanso semanal remunerado entre os portuários de Santos, por exemplo, ver SILVA, Fernando Teixeira da. A carga e a culpa: os operários das Docas de Santos — direitos e cultura de solidariedade 1937-1968. São Paulo: Hucitec; Santos: Prefeitura Municipal de Santos, 1995.
} 
estes juízes e advogados, de sua própria legitimidade.

Artigo recebido em 24 de março de 2013 e aprovado em 21 de maio de 2013.

* Doutora em história pela Universidade Federal do Rio Grande do Sul (UFRGS). Professora da Universidade Federal de Pelotas (UFPel). Bolsista de pós-doutorado Fapergs/Capes. E-mail: clarice.speranza@gmail.com. 